\title{
DUDS annual meeting
}

\section{ÅRSMøDE DUDS 2021}

\section{Fredag | 23. april | 2021 | Auditorium 1 | Rigshospitalet}

\section{Program}

9.00-9.30 Ankomst kaffe

9.30-9:35 Velkomst (Tobias Todsen)

9:35-10.15 Key note speaker: Contrastenhanced ultrasound and microflow imaging (Professor Adrian Lim, Imperial College London)

10.15-10:30 Introduktion af industrien

10:30-11:00 Kaffe og hands-on med industrien

11.00-11:30 Kardiologisk ultralyd (Tor Biering-Sørensen)

11.30-12.00 Brug af kontrast og 3D ultralyd til karkirurgisk diagnostik (Jonas Peter Eiberg)

12.00-12.30 Doppler ultralyd i reumatologien (Lene Terslev)

12.30-13.00 Frokost

13.00-13.30 Ultralydsdiagnostik af nyrecyster (Ole Graumann)

13.30-14.00 Endoskopisk ultralyd til pankreas diagnostik (Peter Vilmann)

14.00-14.30 Fremtidens ultralyd (Jørgen Arendt Jensen)

14.30-15.00 Kaffe og hands-on med industrien

Eftermiddags tema:

Frie foredrag og uddannelse i ultralyd

15.00-16.00 Frie foredrag

16.00 - 17.00 TEMA: uddannelse i ultralyd. Moderator: Peter Thielsen, formand DUDS Ekspertpanel: Martin Tolsgaard, Thomas

Løkkegaard, Lasse Bremholm og

Thomas Vejborg

17.00-17.05 Afslutning og kåring af vinder af frie foredrag

\section{Hands-on kursus: \\ Introduktion til akut ultralyd \\ CAMES/Panum Instituttet $\mathbf{8 . 3 0}-15.00$}

Kurset vil gennemgå ultralydterori og anvendelse af ultralyd $i$ en akutmodtagelse til fokuseret hjerteskanning, E-FAST, DVT og anlæggelse afUL-vejledtPVK. Undervisingen er en kombination af foredrag og praktiske øvelser på figuranter. Læs mere kursus og tilmelding på www.duds.dk

Pris: 750 kr. / gratis for DUDS medlemmer

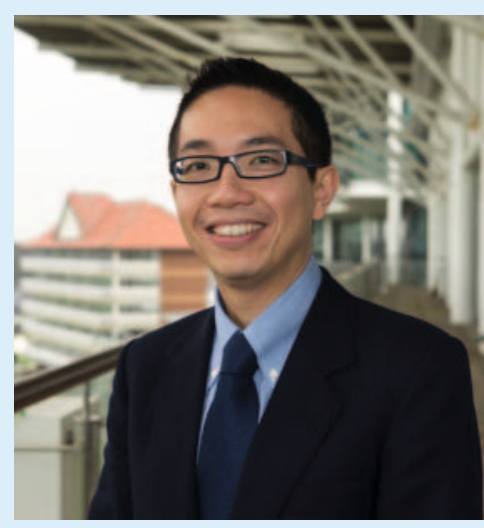

Key note speaker

Prof. Adrian Lim Imperial College London

17.15-18.00 DUDS general forsamling

18.30 Middag for DUDS medlemmer (FOOD CLUB Nørrebro)

\section{Siemens $;$ Calloll Healthineers $\%$ CANON MEDICAL}




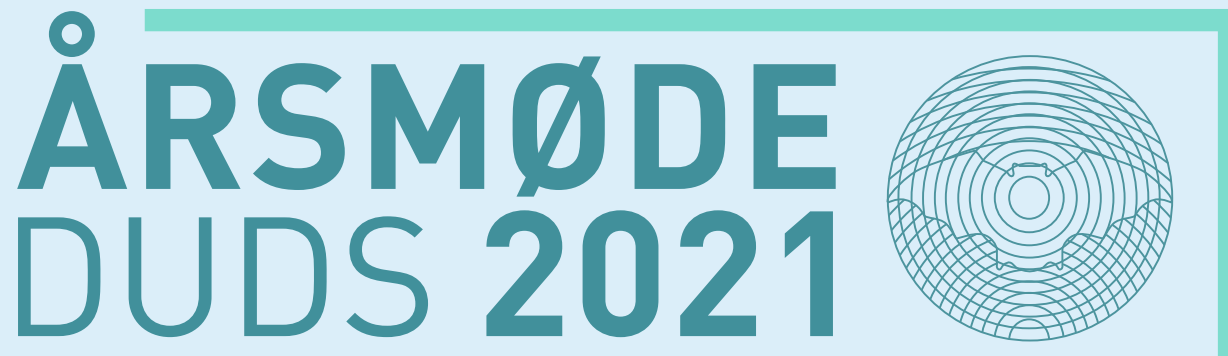

\section{Fredag | 23. april | Rigshospitalet}

Til årsmødet vil vi få besøg af Prof. Adrian Lim fra Imperial College London, som vil holde gæsteforelæsning om kontrastforstærket ultralyd. Derudover vil programmet bestå af en række inspirerende forelæsninger om hvordan ultralyd har været med til at forbedre diagnostikken inden for forskellige specialer. Dagen sluttes af med en foredragskonkurrence med præsentation af nye studier fra forskere, der beskæftiger sig med ultralyd. Indsend gerne abstract til dette og vær med i konkurrencen om at vinde 3000 kr. i DUDS-legat. For DUDSmedlemmer vil der derefter blive afholdt generalforsamling, hvilket afsluttes med fælles middag for interesserede.

Se det fulde program for årsmødet, infomation om tilmelding samt kriterier til indsendelse af abstract til de frie foredrag på www.duds.dk

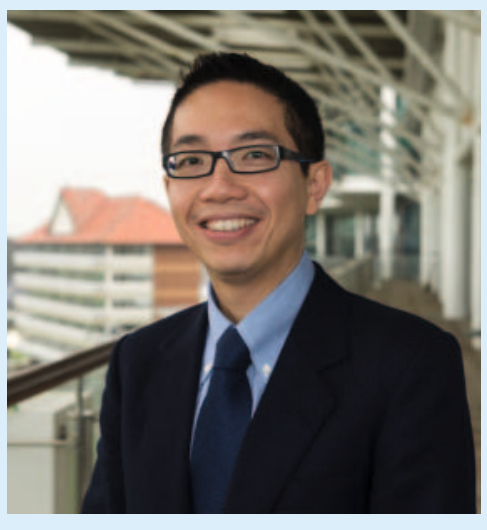

Key note speaker

Prof. Adrian Lim Imperial College London

\section{Årsmødet}

Gratis for alle (kræver dog tilmelding)

Middag kun for DUDS-medlemmer

\section{Hands-on kursus}

750 kr. (gratis for DUDS-medlemmer)

Tilmelding senest den 15. marts via mail til dudstilmeldingagmail.com

Grundet corona er der begrænsede pladser og DUDS-medlemmer vil have fortrinsret i tilfælde af flere tilmeldte end pladser.

\section{SIEMens $;$ Calloll Healthineers $\%$ CANON MEDICAL}

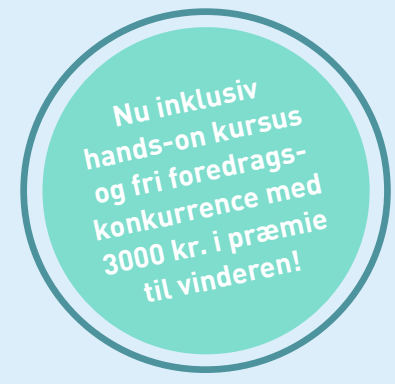

